Universidad de Lima

Facultad de Derecho

Carrera de Derecho

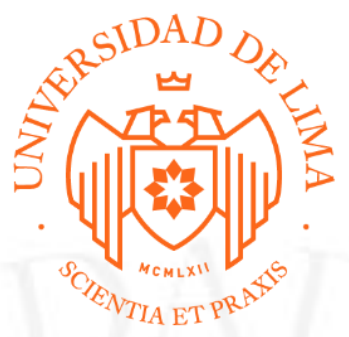

\title{
CIVIL: "DIVORCIO POR CAUSAL" Y TRIBUTARIO: "IGV-PRESTACIÓN DE SERVICIOS"
}

Trabajo de suficiencia profesional para optar el Título Profesional de Abogado

\section{Maria Elena Ugarte Justiniani}

Código 20122274

$$
\text { Lima - Perú }
$$

Junio de 2019 
Materia: Divorcio por causal

$\mathrm{N}^{\circ}$ de Expediente: $183501-2001-01503-0$

\section{RESUMEN}

El expediente consiste en una demanda de divorcio por causal de separación de hecho interpuesto por el cónyuge, quien alega que los elementos de la causal se encuentran completamente acreditados, toda vez que ambos cónyuges se encuentran separados durante más de 30 años. Este proceso fue declarado fundado en la sentencia de segunda instancia. En el escrito de la demanda se presentaron como medios probatorios: una demanda de separación de cuerpos que fue finalmente declarada infundada, la denuncia por abandono injustificado del hogar que motiva el proceso anterior, y demandas de aumento de pensión de alimentos para la cónyuge y la hija.

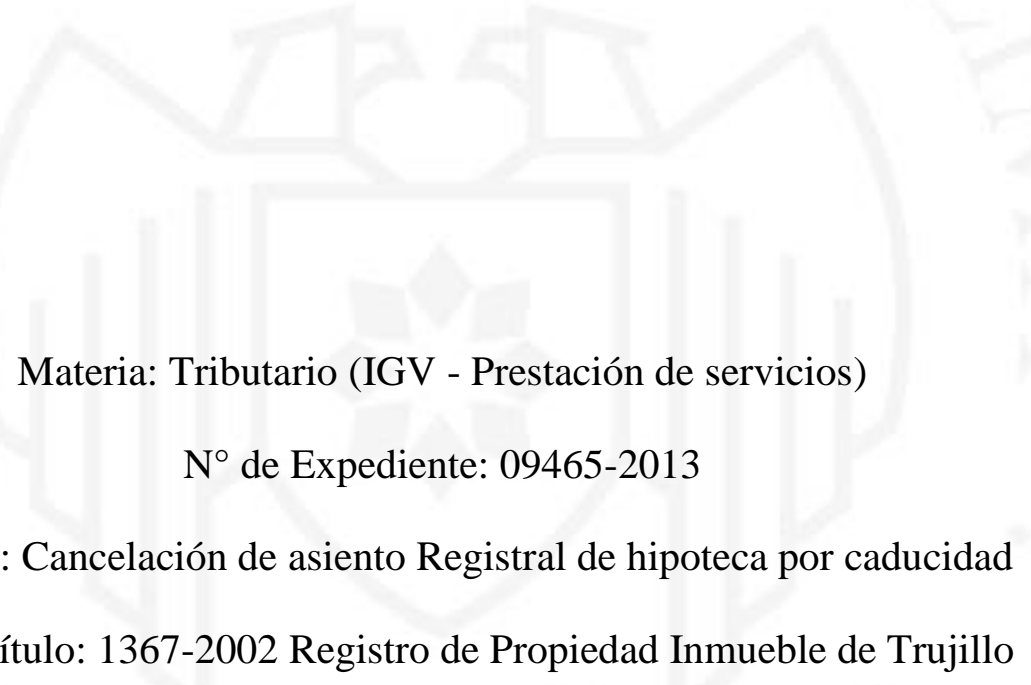

\section{RESUMEN}

El expediente materia de sustentación consiste en un procedimiento contencioso administrativo tributario, mediante el cual el contribuyente impugna los valores emitidos como consecuencia de una fiscalización al IGV e Impuesto a la Renta de tercera categoría de los ejercicios 2008 y 2009. En este caso, los reparos efectuados por la Administración Tributaria se encontraban vinculados con la inclusión de las actividades de transporte realizadas por la Compañía dentro del Apéndice II de la Ley del IGV (servicios exonerados). Este procedimiento culminó en el Tribunal Fiscal, en cuya resolución se revocó la decisión de la SUNAT y se determinó que esta última debía reliquidar los valores. 